\title{
オスラー病に対する鼻腔植皮術
}

\author{
市村 恵一・中村 直也 \\ 田中 利善・岡 良已*
}

\section{Intranasal Dermoplasty for Hereditary Hemorrhagic Telangiectasia}

\author{
Keiichi Ichimura and Naoya Nakamura \\ (University of Tokyo) \\ Toshiyoshi Tanaka \\ (Tokyo University Branch Hospital) \\ Yoshimi Oka \\ (Tokyo)
}

Recurrent epistaxis as a manifestation of hereditary hemorrhagic telangiectasia (HHT, Rendu-Osler-Weber disease) is usually difficult to control. Although no treatment is regarded to be completely efficacious, intranasal dermoplasty (ID), originally described as septal dermoplasty by Saunders, is considered to be the most effective means of management. ID, however, is not well established in Japan. During the last 2 years we performed ID on 2 patients with HHT to reduce the incidence of epistaxis by protecting the fragile vessels from trauma through the application of a split thickness skin graft over the abnormal superficial nasal vessels.

The technical keypoints of ID in our experience are:

a. In order to avoid septal perforation, ID should be performed on only one side of the septum at each procedure with preservation of the septal perichondrium.

b. Exacerbation of bleeding after ID can be attributed to four factors. 1) telangiectasia develops in mucosa not covered by the graft, that is in the posterior half and anterosuperior tip ; 2) abnormal mucosa can regenerate in a denuded area or in the portion where the graft fails to take ; 3 ) the graft contracts over time exposing areas initially covered by the graft ; 4) telangiectasia develops within the graft. Therefore, after the graft has been sutured anteroinferiorly to vestibular skin it should be attached to the perichondrium with fibrin glue, and the area of the anterosuperior remnant of the septal mucosa for suturing should be minimized. The intranasal skin graft should be as large as possible to cover all the denuded areas and to compensate for graft contracture.

c. The graft is usually a split thickness graft. The thicker the graft, the later occurs the development of telangiectasia in the graft, and nasal stuffiness is common. If patients have nasal stuffiness in the preoperative period, the thicker graft will produce the desired effect.

Key words: hereditary hemorrhagic telangiectasia (Rendu-Osler-Weber disease), intranasal dermoplasty (septal dermoplasty), epistaxis, fibrin glue 
はじめに

オスラー病をはじめとして, 血管に広範な異 常のある症例に起こる鼻出血の対処には難渋す ることが多い，現在のところ，こうした症例に 対する治療法には(表 1) に示すようなものが挙 げられるが，絶対的といらべき治療法は未だ確 立されていない．この中で比較的採用されてい るのがエストロゲン内服療法, レーザー照射, 鼻腔植皮術 (intranasal dermoplasty) である. エストロゲンは有效性こそ高(12) ものの，心 筋梗塞, 血栓症をはじめとする副作用の問題か ら一般的治療法にはなり得ないでいる3)。レー ザーが有望であるとした報告が近年相次いだも のの ${ }^{4) ~ 6)}$, 長期効果は芳ばしくない模様であ り ${ }^{3)}$, 反復処置が必要とされる。 この中で効果 が最も確実であろらとされているのが Saunders ${ }^{7}$ により始められた鼻粘膜を切除し, 同部を遊離皮膚によって置換する方法である。 もちろんオスラ一病は一筋縄では行かぬ疾患で あり, 文献上でも鼻腔植皮術は主になるものの， （表 1 ）に示した治療法を組み合わせて対処して 行かねばならない場合が多くなっている，オス ラー病自体が稀な疾患に属するため, わが国に おいては限られた報告しかないらえ, この術式 を行った報告もない．筆者の経験もわずか 3 例 に過ぎないが, 最近経験した 2 例についての経 過を通して学んだ本法の手技上の要点と問題点

表 1 オスラー病の鼻出血の治療法 下線は比較的有効とされ, 頻度の多いもの

\begin{tabular}{l} 
微細損傷を避ける \\
パッキング \\
粘膜電気焼灼 \\
粘膜化学焼灼 \\
鼻中隔軟骨切除 \\
鼻腔植皮術 (遊離皮膚) \\
有茎皮弁移植 \\
遊離血管吻合皮弁移植 \\
レーザー焼灼 (Nd-YAG, KTP, $\mathrm{Co}_{2}$ ) \\
エストロジェン投与 \\
\hline
\end{tabular}

について考察したい.

\section{手術手技}

\section{1. 粘膜切除}

鼻翼から鼻腔底にまわりこむ皮膚切開を置き， それを外方に翻転し良好な鼻腔内の視野を得る (図 1 ). 鼻中隔の皮膚粘膜移行部に切開を置き, そこから剥離子を用いて粘膜剥離を開始する。 剥離の層は鼻中隔矯正術のとさのよらに軟骨膜 下で剥離することなく, 粘膜・軟骨膜間で剥離 することにより，鼻中隔穿孔の発生を防止する。 剥離範囲の後方限界は中鼻甲介の前端相当部の やや後方とする．下方鼻中隔骨部と鼻腔底に拉 いては骨膜粘膜間を剝離するのは困難であり, ここでは骨膜下の剥離とする. 粘膜の剥離方法 は原法では鋭匙で引っ蛍くのみ7) 11) であるが， 不必要な出血を減らすためにも，手技的には難 しいが剝離子を用いた方法を採用した。剥離終 了後, 軟骨や骨から挙上された鼻中隔粘膜を形 成剪刀で鋏切する. 鼻腔底部後方粘膜に対して は剪刀による操作は困難なため, 三角メスなど による切開とする．さらに下鼻甲介粘膜を下甲 介剪刀で広範囲に切除する. 鼻翼切開を加えて も, 明視下に操作出来る限界は入口部から 3〜4 $\mathrm{cm}$ 位までである. 切除断端からの出血はバイ ポーラー電気凝固により確実に止める.

\section{2. 皮膚置換}

移植皮膚は通常大腿部から採取する。その厚 さは中間層とする.図 2 で示した粘膜欠損部を
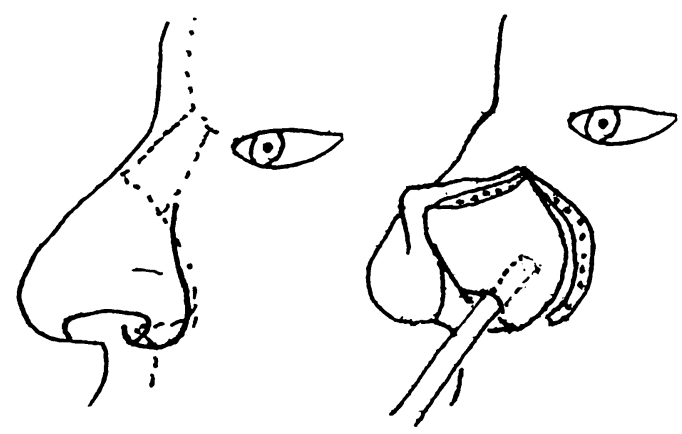

図 1 鼻腔植皮術のアプローチ法 左は皮膚切開, 右は粘膜, 軟骨膜下剝離を示す. 
すべて覆らためには $10 \times 5 \mathrm{~cm}$ 程度の大ささが 必要である。これを先の操作で露出した鼻中隔 軟骨膜上にまずかぶせ，鼻腔底，下鼻甲介の方

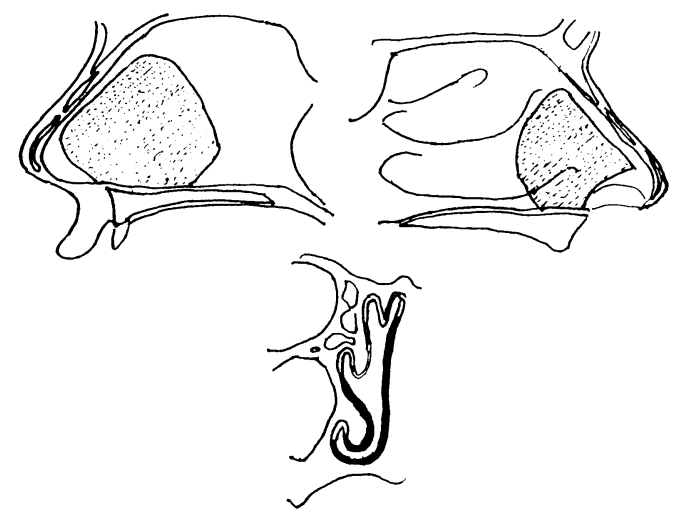

図 2 皮膚置換範囲

上の斜線部と下の黒い部分が対象範囲.
に伸ばし広げる，鼻中隔にかぶせた部分では， 鼻前庭の皮膚(前方), 残存粘膜(上方) と縫合す る. 後方や下鼻甲介上部での縫合は困難であり， 縫合部より後方は少しずつフィブリン糊で固定 してゆき後方まで達し, 最後は粘膜面上に被せ て糊付けする.採皮部の処置は通常の植皮と同 様でよい.

\section{3 . 術後操作}

移植皮膚の確実な生着のためには血腫を防止 する必要がある。フィブリン糊固定が十分なら タンポンなしでもよいが，ある程度の圧迫があ った方が安心なので，手術完了段階での出血は ほとんどないものの, 軟骨ガーゼを軽く挿入し ている. 鼻翼切開を縫合して手術は終了する. ガーゼ抜去，抜糸は術後 5 日目頃行う.

\section{成績および術後経過}

2 名の才スラー病に対する鼻腔植皮術の結果

表 2 鼻腔植皮術施行症例内訳

\begin{tabular}{|c|c|c|c|c|}
\hline 症例 & \multicolumn{2}{|c|}{1} & \multicolumn{2}{|c|}{2} \\
\hline 年齢 & \multicolumn{2}{|c|}{12} & \multicolumn{2}{|c|}{37} \\
\hline 性 & \multicolumn{2}{|c|}{ 男 } & \multicolumn{2}{|c|}{ 女 } \\
\hline 発症 & \multicolumn{2}{|c|}{2 歳 } & \multicolumn{2}{|c|}{ 幼時 } \\
\hline 悪化 & \multicolumn{2}{|c|}{3 年前 } & \multicolumn{2}{|c|}{7 年前 } \\
\hline 家族歴 & \multicolumn{2}{|c|}{+} & \multicolumn{2}{|c|}{-} \\
\hline 貧血 & \multicolumn{2}{|c|}{$+(\mathrm{Hb} 8$ 台 $)$} & \multicolumn{2}{|c|}{$+(\mathrm{Hb} 6$ 台 $)$} \\
\hline \multirow[t]{2}{*}{ 手術側 } & \multicolumn{2}{|c|}{ 左 $\rightarrow$ 右 } & \multicolumn{2}{|c|}{ 右 $\rightarrow$ 左 } \\
\hline & 左 & 右 & 右 & 左 \\
\hline 手術時間 & $3 \mathrm{~h} 30 \mathrm{~m}$ & $2 \mathrm{~h} 5 \mathrm{~m}$ & $2 \mathrm{~h} 50 \mathrm{~m}$ & $2 \mathrm{~h} 20 \mathrm{~m}$ \\
\hline 出血量 & $70 \mathrm{ml}$ & $50 \mathrm{ml}$ & $100 \mathrm{ml}$ & $40 \mathrm{ml}$ \\
\hline 移植範囲 & $\begin{array}{l}\text { 鼻中隔, 底部 } \\
(1 \text { 片 })\end{array}$ & $\begin{array}{l}\text { 鼻中隔, 底 } \\
\text { 部, } \\
(2 \text { 片 })\end{array}$ & $\begin{array}{l}\text { 鼻中隔, 底 } \\
\text { 部( } 1 \text { 片) }\end{array}$ & $\begin{array}{l}\text { 鼻中隔, 底 } \\
\text { 部, } \\
(1 \text { 片), 右 } \\
\text { 下鼻甲介 }\end{array}$ \\
\hline 移植片の経過 & 生着良好 & 生着良好 & 生着良好 & 右は脱落 \\
\hline 術後出血 & なし & 汪とんどなし & $\begin{array}{l}\text { 下鼻甲介, 前 } \\
\text { 上方粘膜か } 5\end{array}$ & $\begin{array}{l}\text { 右下鼻甲介, } \\
\text { 前上粘膜, } \\
\text { 左前上方粘膜 } \\
\text { から }\end{array}$ \\
\hline 中隔穿孔 & & & & \\
\hline
\end{tabular}


を(表 2 )に示す. 術後の鼻中隔穿孔は鼻中隔粘 膜剥離の層に問題があった 1 例に生じた。これ は2 回目の左側粘膜剝離時に誤って軟骨に裂が 生じてしまったもので, 術後暫くして穿孔が生 じ，徐々に拡大し直径 $7 \mathrm{~mm}$ の大きさになった ものである. 何れの症例に扣いても術後は鼻出 血の頻度，量とも著明に減少した。出血部位は 特に前上方の粘膜残存部，下鼻甲介の皮膚移植 脱落部であった。まだ術後経過が短いためもあ ろらが，移植皮膚からの出血は経験していない， 症例 1 は術後治療を特に要さない状態である。 症例 2 は時々出血があり, 自身で綿花を挿入し て止血して拈り，出血量がやや多い場合は受診 してスポンゼル®(止血用ゼラチンスポンジ)を 挿入すれば容易に止血する状態である。

\section{考察}

1. 鼻腔植皮術の手技上の問題点

オスラー病に括ける易出血性の本態は血管筋 層の欠如，内膜の異常とそれに因る血管拡張で

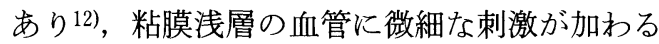
だけで容易に出血する．刺激の加わりやすい前 方の粘膜, 特にキーゼルバッ八部位が最も多い 出血部位である7).

Saunders ${ }^{7)}$ が最初に報告したのは鼻中隔粘膜 のみの切除と皮膚による置換であったので septal dermoplasty（鼻中隔植皮術）と呼ばれたが， 効果を確実なものとするため，その後は鼻腔底 や下鼻甲介粘膜も皮膚置換する方法が推奖され ている8) 11). したがって現在では鼻腔植皮術 とするのが適切と思われる. 切除置換範囲はで きるだけ大きくすることが好ましいので，鼻翼 切開を行い，良好な視野を得ることが必要とな る.

術後の鼻中隔穿孔を避けるために粘膜剝離の 際の層に注意することは重要である，鼻中隔矯 正術に扮けるように軟骨膜下剝離を行らと血行 障害のため，後に穿孔が生じ，それが次第に拡 大してくる．同様に，両側を同時に操作すると 穿孔が生じやすいので，片側ずつ時間を置いて 行うのが好ましい，筆者は 6 カ月以上間を置い
ている.

鼻腔植皮術の目的は粘膜を皮膚で置換するこ とにより，被覆支持組織の厚みと強度がその下 の血管壁の損傷の機会を減らすことにある．粘 膜を切除したからといって，そこを皮膚で覆わ ない限り，易出血性は変わらない，皮膚で置換 すれば出血頻度は激減するものの，出血がなく なるわけではない，その理由は以下の 4 点であ る.

(1)置換し得ない粘膜が残り，そこから出血す る. 鼻腔後半が該当する．また，移植した皮虐 の縫合に関し，前下方は皮膚と縫合できるが， 前上方は粘膜しかなく，この部で縫い代用に残 した粘膜から出血することが多い。

(2)移植皮膚が生着しないで脱落した場合，そ こから出血する.

(3)一旦生着した移植皮膚が縮小し，一度は覆 われた粘膜面が再露出し，そこから出血寸る.

(4)血管が再生し, 移植した皮膚表面に達し, そこから出血する13)。

1）皮膚置換範囲と縫合に関する問題

(1)の後方からの出血は頻度からいってほとん ぞ問題とならない，移植皮膚の確実な生着のた めにはそれと周囲組織とを縫合することが基本 であるし，また皮下血腫の防止のため挿入する 軟骨ガーゼの出し入れの際に安定を保つために も縫合は理に叶う。軟骨ガーゼを用いずにメ ローセル®(ポリビニルアルュール製吸湿性ス ポンジ)を用いたり，ガーゼと移植皮膚の間に ベスキチン®(キチン膜)や絹布片などを置くと ガーゼ抜きの際にずれが起こらなくすることが 出来る．そらすれば縫合なしで糊付けだけで済 ますことも可能である，ただし，縫合のための 縫い代残しを図らなくても，技術上の問題で, 粘膜切除に鋏を使用する限り粘膜は残ってしま らので，この部の切除に三角入スを用いるとか， その部のみは小鋭匙で搔爬するだけとするなど の工夫がいる．また移植片の安定を図るため, その中央部に貫通する縫合を置くことも 1 つの 方法である。ただしこれは既に他側が皮膚置換 
されている場合はよいが，初回例だと対側の粘 膜からの出血の制御が必要となる.

2 ）移植皮膚の大きさと厚さに関する問題

(2)に関しての筆者の経験では，移植皮膚が十 分大きく 1 つで欠損部全面を覆える程度のもの であるならば問題はないが，複数の皮膚片を用 いると，下鼻甲介部で移植片が脱落することが あり，その場合下鼻甲介前面から出血が反復す ることになる. (3)の経験はないが，そうした点 も考慮し，予め移植皮虐を粘膜欠損部より大き めにとることが重要であろう.

(4)と関連する，移植する皮膚の厚さについて は，通常は中間層皮膚弁がよいとされる，中間 層植皮の厚さも様々であり，0.008～0.012イン チが薄い中間層，0.015 0.018インチが平均的 中間層，0.018 0.022インチが厚い中間層と分 類されている. 本法の考案者の Saunders の文 献をみても，採用する厚さは報告の度に異なっ て抎り, 0.02〜0.025インチ7), 0.02インチ9), 0.0 $18 \sim 0.02$ インチ10), 0.014 インチ11) と次第に薄 くなっている．皮膚が厚ければ出血は起こりに くくなるが，鼻腔断面積が減少するために鼻閉 が起こる，予め鼻閉が高度であった鼻アレル ギーを合併した症例 2 に対しては，移植皮虐を 厚くしたところ，鼻閉を除いてアレルギー症状 も改善し, 出血もないよい結果を得ている.

2.オスラー病に打ける鼻出血治療法の選択 鼻腔植皮術を行っても長期的に見れば様々な 理由で再び出血が起こる例が多くなるので, 厳 密にはその効果は一時的である14)。しかし，少 なくとも一定期間は出血の恐怖から逃れられる 点で，施行する価值が十分にある手術であると 考光る. Harrisson ${ }^{2)}$ はオスラ一病の治療選択 基準は病変部位, 粘膜の状態, 出血頻度, quality of life，精神状態などにより決定する必 要があるが，若年者や手術可能例には鼻腔植皮 術を，これで制御し得ないものや広範な病変の 例にはエストロゲンを勧めるとしている。レー ザー照射 (Nd-YAG, KTP) も永続性はないが,

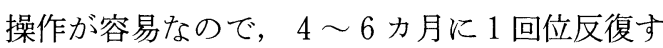

るのがよいとされる．鼻腔植皮術とレーザー治 療を組反合わせるのが最も有用とされている31.

\section{まとめ}

鼻腔植皮術を行らにあたって経験上肝要と思 われる点をまとめると以下のごとくになる.

(1)鼻中隔の処理は必ず一側ずつ行う.

(2)剥離の際，鼻中隔の軟骨膜は残す。

(3)縫合のための縫い代(粘膜残存部)は出来る だけ少なくする。

(4)下鼻甲介粘膜も置換する汪らがよい.

(5)移植皮膚は粘膜切除部を 1 つで覆えるよう に出来るだけ大きなものとする。

6)移植皮膚の厚さは中間層でよいが，鼻閉の ある鼻アレルギーを合併する例では厚めがよい。

本論文の要旨は第32回日本鼻科学会学術講演会に 执いて報告した.

\section{文献}

1) Harrison DFN : Familial haemorrhagic telangiectases; a survey of a series treated by oestrogen therapy. J Laryngol Otol 71 : 577 596, 1957.

2) Harrison DFN : Use of estrogen in the treatment of familial hemorrhagic telangiectasia. Laryngoscope $92:$ 314 319, 1982.

3) Siegel MB, Keane WM, Atkins JP Jr, et al : Control of epistaxis in patients with hereditary hemorrhagic telangiectasia. Otolaryngol Head Neck Surg $105: 675 \sim 679,1991$.

4) Ben-Bassat M, Kaplan I and Levy R : Treatment of hereditary haemorrhagic telangiectasia of the nasal mucosa with the carbon dioxide laser. Br J Plast Surg 31 : 157 158, 1978.

5) Parkin JL and Dixon JA : Laser photocoagulation in hereditary hemorrhagic telangiectasia. Otolaryngol Head Neck Surg 89 : 204 208, 1981.

6) Shapshay SM and Oliver P : Treatment of hereditary hemorrhagic telangiectasia by NdYAG laser photocoagulation. Laryngoscope $94: 1554 \sim 1556,1984$.

7) Saunders WH : Septal dermoplasty for control 
of nosebleeds caused by hereditary hemorrhagic telangiectasia or septal perforations. Trans Am Acad Ophthalmol Otolaryngol 64 : 500 506, 1960.

8) Saunders WH : Hereditary hemorrhagic telangiectasia; its familial pattern, clinical characteristics, and surgical treatment. Arch Otolaryngol $76: 245 \sim 260,1962$.

9) Saunders WH : Septal dermoplasty; a new procedure for control of nose bleeds in patients with hereditary haemorrhagic telangiectasia. J Laryngol Otol 77 : 69 76, 1963.

10) Saunders W: Hereditary hemorrhagic telangiectasia ; effective treatment of epistaxis by septal dermoplasty. Acta Otolaryngol 58 : 497 $\sim 502,1964$.

11) Saunders WH : Septal dermoplasty ; ten years experience. Trans Am Acad Ophthalmol Otolaryngol $72: 153 \sim 160,1968$.

12) Jahnke V : Ultrastructure of hereditary telangiectasia. Arch Otolaryngol 92 : 262 265, 1970.

13) McCabe WP and Kelly AP Jr : Management of epistaxis in Osler-Weber-Rendu disease ; recurrence of telangiectasia within a nasal skin graft. Plast Reconstr Surg 50 : 114 118, 1972.

14) Ulsø C, Vase $P$ and Stoksted $P$ : Long-term results of dermoplasty in the treatment of hereditary haemorrhagic telangiectasia. J Laryngol Otol $97: 223 \sim 226,1983$.

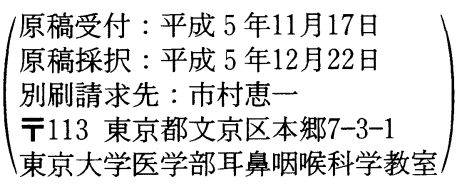

